\title{
THE FLEXIBLE FUND ANNUITY: VALIC REVISITED
}

Within the last decade the Securities and Exchange Commission has asserted its jurisdiction over two areas-insurance and bankinghitherto thought outside its purview because of specific statutory exemptions. ${ }^{1}$ Because "all investors in mutual funds, by whomever spon-

1 SEC v. Variable Annuity Life Ins. Co. of America, 359 U.S. 65 (1959) ( $V A L I C)$; First Nat'l City Bank, SEC Investment Company Act Release No. 4538, March 9, 1966.

The Securities Act of 1933 provides:

Section 2. When used in this title, unless the context otherwise requires-

(1) The term "security" means any note, stock, treasury stock, bond, debenture, evidence of indebtedness, certificate of interest or participation in any profit sharing agreement, collateral-trust certificate, preorganization certificate or subscription, transferrable share, investment contract, voting-trust certificate, certificate of deposit for a security, fractional undivided interest in oil, gas, or other mineral rights, or, in general, any interest or instrument commonly known as a "security," or any certificate of interest or participation in, temporary or interim certificate for, receipt for, guarantee of, or warrant or right to subscribe to or purchase, any of the foregoing.

48 Stat. 74 (1933), 15 U.S.C. \$77b(1) (1964).

Section 3(a). Except as hereinafter expressly provided, the provisions of this title shall not apply to any of the following classes of securities:

..

(8) Any insurance or endowment policy or annuity contract or optional annuity contract, issued by a corporation subject to the supervision of the insurance commissioner, bank commissioner, or any agency or officer performing like functions, of any State or Territory of the United States or District of Columbia.

48 Stat. 75 (1933), 15 U.S.C. $\$ 77 \mathrm{c}(\mathrm{a})$ (8) (1964).

The $\$ 3(a)$ (8) exemption has been criticized as being excessively cautious because without it the $\$ 2(1)$ definition could not have been construed to include insurance policies; thus the exemption creates an implication that the $\$ 2(1)$ language includes insurance policies, which was not the intent of Congress. 1 Loss, SEcuritres REgulation 497 (1961). However, it has also been argued that, since the exemption goes only to policies issued by state-regulated insurance companies, the term "security" extends to insurance policies and $\S 3(\mathrm{a})(8)$ carved out an exemption for those policies which Congress felt were not in need of federal regulation. Mundheim \& Henderson, Applicability of the Federal Securities Lazes to Pension and ProfitSharing Plans, 29 LAW \& Contemp. Prob. 805 n.33 (1964). For the history of this section (or lack of it), see Landis, The Legislative History of the Securities Act of 1933, 28 GEo. WASH. L. REv. 29, 46 n.24 (1959).

The Investment Company Act of 1940 provides:

Section 3(a). When used in this title, "investment company" means any issuer which-

(1) is or holds itself out as being engaged primarily, or proposes to engage primarily, in the business of investing, reinvesting, or trading in securities;

-

(3) is engaged or proposes to engage in the business of investing, reinvesting, owning, holding, or trading in securities, and owns or 
sored, should enjoy the same protections,"2 the SEC has contended that the exemptions were not intended by Congress to allow these industries to operate mutual funds outside the scheme envisioned by the major securities legislation passed between 1933 and 1940.

This Comment will consider the position recently taken by the United Benefit Life Insurance Company that its variable annuity is entitled to the exemptions for insurance policies and insurance companies. The Supreme Court has recently granted certiorari to review the determination by the Court of Appeals for the District of Columbia Circuit that United Benefit was entitled to such exemptions. ${ }^{3}$ At least one bank has acquiesced in the assertion by the SEC of jurisdiction over its entry into the mutual fund field, but the issues as related to banks will not be discussed in this Comment. ${ }^{4}$

The insurance industry has traditionally offered a "fixed annuity," which provides for a fixed amount of income to its purchaser, usually paid in monthly installments, regardless of how long he lives. It offers to the purchaser (annuitant) the assurance that, although he is consuming his capital, he will never outlive it as he might if he were to deduct periodically some particular amount from his savings to cover living expenses. A similar annuity, the "participating annuity,"

proposes to acquire investment securities having a value exceeding

40 per centum of the value of such issuer's total assets (exclusive of

Government securities and cash items) on an unconsolidated basis.

54 Stat. 797 (1940), 15 U.S.C. \$ 80a-3(a) (1964).

Section $3(c)$. Notwithstanding subsections (a) and (b), none of the fol-

lowing persons is an investment company within the meaning of this title:

(3) Any bank or insurance company ....

54 Stat. 798 (1940), 15 U.S.C. $\$ 80 \mathrm{a}-3$ (c) (3) (1964).

2 Hearings Before a Subcommittee of the Honse Committee on Government Operations, 88th Cong., 1st Sess. 4 (1963) (statement of William L. Cary, Chairman of the SEC). The SEC is not alone in this view. In a letter to the Chairman of the Senate Committee on Banking and Currency commenting on the advisability of the enactment of an exemption from federal securities legislation for bank-sponsored mutual funds, the Chairman of the Board of Governors of the Federal Reserve System stated: "The adverse position taken by the Board was based upon its belief that investor protection as to all investments of a similar nature can be best effected by a uniform statutory and regulatory plan administered by a single governmental agency." Hearings Before a Subcommittee of the Committee on Banking and Currency on $S$. 2704, 89th Cong., 2d Sess. 24 (1966).

3 SEC v. United Benefit Life Ins. Co., 359 F.2d 619 (D.C. Cir. 1966), cert. granted, 385 U.S. 918 (1966).

4 The price of the bank's acquiescence was the grant by the SEC of exemptions from the following sections, inter alia, of the Investment Company Act: $\$ 10$ (b) (2), 54 Stat. 806 (1940), 15 U.S.C. $\$ 80 \mathrm{a}-10$ (b) (2) (1964), prohibiting the use of an affiliated company as underwriter of an investment company unless a majority of the board of directors of the investment company are not associated with the underwriter; $\$ 10(\mathrm{~b})(3), 54$ Stat. 806 (1940), 15 U.S.C. $\$ 80 \mathrm{a}-10$ (b) (3) (1964), prohibiting an investment company from having a majority of its board of directors affiliated with an investment banker; and $\$ 10(\mathrm{c}), 54$ Stat. 806 (1940), 15 U.S.C. $\$ 80 \mathrm{a}-10$ (c) (1964), prohibiting an investment company from having as a majority of its board of directors persons who are officers or directors of any one bank. First Nat'1 City Bank, Investment Company Act Release No. 4538, March 9, 1966. A discussion of the issues relating to the exemptions for the banks can be found in Mundheim \& Henderson, supra note 1, at 819-37. See also H.R. REP. No. 2337, 89th Cong., 2d Sess. 35-37 (1966) [hereinafter cited as MUTUAL Fund ReporT]. 
provides for additional payments when the underwriter has favorable mortality or investment experience, i.e., the annuitant participates in the profitability of the insurance company. The additional payments under a participating annuity are small and usually do not fluctuate to any large extent. Either annuity can be purchased in a lump sum or by monthly premiums paid out of the annuitant's earnings. ${ }^{5}$

In response to public criticism that, because of the postwar inflation, annuity benefits were substantially diminished in real value as compared to the premiums paid to the insurer, the insurance industry developed the "variable annuity," so called because the benefits vary with the investment performance of a fund composed largely of common stocks. Under this plan, the annuitant purchases units of interest (shares) in a fund composed primarily of equity securities. At the time the purchaser has completed the payments called for by the contract, he has the option of withdrawing the total value of his interest in the fund in $\mathrm{cash}^{6}$ or having his interest paid out to him as follows. The accumulated cash value of his units of interest is used to calculate the dollar amount of the monthly payment which that sum would generate if used to purchase a fixed annuity. This dollar amount is then divided by the current value of a unit of interest in the fund in order to determine the number of units which will be paid periodically to the annuitant for the rest of his life. ${ }^{7}$ Hence the value of the benefits paid to the annuitant vary directly with the investment performance of the fund both before and after maturity, and the annuitant bears the investment risk while the sponsoring company bears the insurance riskthe risk that the annuitant will live longer than predicted. ${ }^{8}$

5 For a general description of these annuities, see HUEBNER \& BLACK, LIFE INSURANCE 104-16, 387-98 (6th ed. 1964); Maclean, LIFE Insurance 53-63 (9th ed. 1962).

6 Upon payment of a small charge, the purchaser may also redeem his interest in the fund at any time prior to the end of the pay-in period. See concurring opinion of Mr. Justice Brennan in SEC v. Variable Annuity Life Ins. Co. of America, 359 U.S. 65,84 n.25 (1959) (VALIC).

7 Assume the value of the annuitant's interest in the fund at the end of the pay-in period is $\$ 30,000$. (This amount will include a total of all premiums paid in plus a pro rata share of capital gains-or losses-and dividend payments.) If used to purchase a fixed annuity at age sixty-five, this amount would generate a monthly payment of $\$ 220.20$. See HureBNER \& BLACK, op. cit. supra note 5, at 109. Assuming that the current value of a unit of interest in the fund is presently $\$ 25$, the annuitant will receive $8.81(220.20 \div 25)$ units of interest from the fund, regardless of their future value, each month for the rest of his life.

8 A more extensive description of the variable annuity appears in the concurring opinion of Mr. Justice Brennan in SEC v. Variable Annuity Life Ins. Co. of America, 359 U.S. 65, 81-87 (1959) (VALIC), and in Johnson, The Variable Ammity: What It Is and Why It Is Needed, 1956 INs. L.J. 357. The terms of a typical variable annuity contract are set out in full as an appendix to the district court's opinion in SEC v. Variable Annuity Life Ins. Co. of America, 155 F. Supp. 521, 529-38 (D.D.C. 1957).

Some variable annuity contracts provide disability insurance waiving the payment of premiums if the annuitant becomes disabled, as well as term insurance on the life of the annuitant for the first five years of the pay-in period, the latter costing the company about $2 \%$ of the annual premiums. For persons deemed uninsurable, the 
Because of the similarity between the annuitant's interest in the "Separate Account" (the insurance term for the fund composed of all the paid-in premiums of variable annuity contract holders) and the shareholder's interest in a mutual fund, ${ }^{9}$ the SEC brought suit in 1957 against the major issuer of variable annuities, Variable Annuity Life Insurance Company of America (VALIC), to prohibit it from selling the policies without registering them under the Securities Act of $1933,{ }^{10}$ and to compel registration of the company itself under the Investment Company Act of $1940 .{ }^{11}$ VALIC resisted on the ground that the variable annuity was an annuity exempted by the Securities Act ${ }^{12}$ and the company was an insurance company exempt from the Investment Company Act. ${ }^{13}$ Since VALIC was regulated by the Insurance Commissioner of the District of Columbia, it also claimed the protection of the McCarran-Ferguson Act, which prohibits the application of federal legislation not specifically dealing with insurance to the business

above provisions are not made when the contract is issued. SEC v. Variable Annuity Life Ins. Co. of America, 359 U.S. 65, 82 (1959) (VALIC). With regard to companies dealing exclusively in variable annuities, the SEC has required that these risks be farmed out to conventional insurance companies. Variable Annuity Life Ins. Co. of America, 39 S.E.C. 680, 685-91 (1960).

9 "Mutual fund" is the popular name for an open-end investment company, which offers to its stockholders diversification of investment and expert financial management by pooling the capital of the shareholders in a large fund in which each stockholder retains a pro rata interest based on the amount of his contribution to the fund. Most mutual funds are "externalized," i.e., the fund employs separate entities to supply it with financial advice ("investment advisor") and underwriting services ("principal underwriter"). See generally MUTUAL Fund REPORT 45-59; SEC, Report of the Special Study of Securities Markets, H.R. Doc. No. 95, pt. 4, 88th Cong., 1 st Sess. 95-99 (1963) [hereinafter cited as SpECIAI STUDY].

10 Section 6(a) of the Securities Act provides: "Any security may be registered with the Commission under the terms and conditions hereinafter provided, by filing a registration statement . . . 48 Stat. 78 (1933), 15 U.S.C. \$ 77f(a) (1964). Although the act nowhere requires registration, $\$ 5$ makes such prohibitions relating to the use of interstate commerce and the mails in connection with unregistered securities as to compel registration of nearly any security an issuer or underwriter might desire to sell. 48 Stat. 77 (1933), as amended, 15 U.S.C. $\$ 77 \mathrm{e}$ (1964).

11 With regard to investment companies, $\$ \$ 7(a)$ and $8(a)$ of the Investment Company Act, 54 Stat. 802 (1940), 15 U.S.C. $\$ \$ 80 a-7$ (a), 8(a) (1964), operate in a manner identical to $\$ \S 5$ and $6(a)$ of the Securities Act. See note 10 supra.

12 See note 1 supra.

13 Section 3(c) (3) of the Investment Company Act, note 1 supra, exempts insurance companies. The Investment Company Act defines "insurance company" in $\S 2(a)(17)$ as

a company which is organized as an insurance company, whose primary and predominant business activity is the writing of insurance or the reinsuring of risks underwritten by insurance companies, and which is subject to supervision by the insurance commissioner or a similar official or agency of a State; or any receiver or similar official or any liquidating agent for such a company, in his capacity as such.

54 Stat. 793 (1940), 15 U.S.C. \$ 80a-2(a) (17).

Because VALIC's sole business was the issuance of variable annuities, it could not contend, as the Prudential Insurance Company did subsequently, see text accompanying notes 32-33 infra, that even if the variable annuity were a security, the company's principal business was insurance. 
of insurance. ${ }^{14}$ Both the district court ${ }^{15}$ and the court of appeals ${ }^{16}$ agreed with VALIC, although they recognized that the status of the variable annuity was not free from doubt. ${ }^{17}$

In SEC v. Variable Annuity Life Ins. Co. of America (VALIC), ${ }^{18}$ the Supreme Court, reversing the lower courts in a five-four decision, treated as common to all three acts the issue of whether the variable annuity was a security or an insurance policy. Although the Court did not articulate why the three acts related to this one issue, the Third Circuit in Prudential Ins. Co. of America v. SEC ${ }^{19}$ apparently assumed that the Supreme Court's reason for dealing with the Securities Act and the Investment Company Act simultaneously was that, if the variable annuity was a security, its issuer was not an insurance company since the issuer's sole business was the sale of variable annuities. It seems that a similar argument applies to the treatment of the McCarran-Ferguson Act, since it is cast in terms of "the business of insurance," and therefore the act does not apply if the variable annuity is a security rather than insurance. "Business of insurance" could be read to include all business done by insurance companies subject to state regulation, and such an interpretation would include the variable annuity. But this latter interpretation is negated by the legislative history, which indicates that the McCarran-Ferguson Act is irrelevant to any interpretation of the federal securities legislation. It was passed in response to the 1944 decision in United States $v$. South-Eastern Underworiters $A s s^{\prime} n{ }^{20}$ in which the Supreme Court held that the insurance

14 Section 2 of the McCarran-Ferguson Act provides:

(a) The business of insurance, and every person engaged therein, shall be subject to the laws of the several States which relate to the regulation or taxation of such business.

(b) No Act of Congress shall be construed to invalidate, impair or supersede any law enacted by any State for the purpose of regulating the business of insurance, or which imposes a fee or tax upon such business, unless such Act specifically relates to the business of insurance: Provided, That . . the Sherman Act, and . . the Clayton Act, and . . the Federal Trade Commission Act, as amended, shall be applicable to the business of insurance to the extent that such business is not regulated by State law.

59 Stat. 34 (1945), as amended, 15 U.S.C. \$ 1012 (1964).

15 SEC v. Variable Annuity Life Ins. Co. of America, 155 F. Supp. 521 (D.D.C. 1957). The district court held that the variable annuity came within the purview of the securities legislation but that the McCarran-Ferguson Act required federal abstention from regulation. Compare text following note 19 infra.

16 SEC v. Variable Annuity Life Ins. Co. of America, 257 F.2d 201 (D.C. Cir. 1958). The court of appeals affirmed on the ground that an insurance company is any company which is regulated by a state insurance commission. This ignores the statutory requirement of $\S 2(\mathrm{a})(17)$ of the Investment Company Act, note 13 sipra, that an insurance company is one whose business is insurance and is subject to state regulation.

17 In ruling on the status of the variable annuity, the district court observed: "The contending parties appeal to this Court to brand the creature for proper classification. This Court, however, finds that Congress has kept the only branding iron." 155 F. Supp. at 528.

18359 U.S. 65 (1959).

19326 F.2d 383 (3d Cir.), cert. denied, 377 U.S. 953 (1964). See note 13 supra.

20322 U.S. 533 (1944). 
industry was subject to the Sherman Antitrust Act, ${ }^{21}$ thus overruling Paul $v$. Virginia, ${ }^{22}$ which had held that insurance policies were not interstate commerce on the ground that there could be no commerce in intangibles. ${ }^{23}$ The insurance industry had responded to the SouthEastern Underwriters decision by refusing to conform to state regulation, arguing that the Supreme Court had construed their business to be interstate commerce and hence not subject to state regulation. ${ }^{24}$ The House committee report on the McCarran-Ferguson bill declared:

It is not the intention of Congress in the enactment of this legislation to clothe the States with any power to regulate or tax the business of insurance beyond that which they had been held to possess prior to the decision of the United States Supreme Court in the South-Eastern Underweriters Association case. $^{25}$

In light of this legislative history, the McCarran-Ferguson Act should be interpreted narrowly in terms of its specific purpose-to exercise Congress' newly found power to subject insurance companies to the federal antitrust laws (but only to the extent that the states did not assume this task), and to refrain from encroaching upon any power to tax and regulate insurance companies previously exercised by the states. The act was intended to insure that construction of prior federal legislation would be unaffected by the South-Eastern Underwriters case; so interpreted, the act would not withdraw any power which Congress had already specifically vested in the SEC to regulate the insurance business. ${ }^{26}$ Consequently, the McCarran-Ferguson Act has no relevance to the interpretation of the federal securities act. ${ }^{27}$

In making the crucial determination that a variable annuity was a security rather than insurance, the opinion of the Court in VALIC reasoned that, since " insurance' involves a guarantee that at least some

2126 Stat. 209 (1890), as amended, 15 U.S.C. $\$ 11-6$ (1964).

2275 U.S. (8 Wall.) 168 (1868). The Panl decision had been reaffirmed in Hooper v. California, 155 U.S. 648 (i895), and New York Life Ins. Co. v. Deer Lodge County, 231 U.S. 495 (1913).

23 It is doubtful that this reasoning ever commanded much of a following. See cases cited in United States v. South-Eastern Underwriters Ass'n, 322 U.S. 533, 546 n.25 (1944).

24 See H.R. Rep. 143, 79th Cong., 1st Sess. 2 (1945).

25 Id. at 3.

26 It might also be argued that, since the Securities Act and Investment Company Act exempt only regulated insurance policies and insurance companies, see notes 1 \& 13 supra, they both specifically relate to the business of insurance, thus falling without the McCarran-Ferguson Act, which exempts from its scope any federal legislation that "specifically relates to the business of insurance." See note 14 supra.

27 For cases considering the interplay between the Securities Act of 1933 and the McCarran-Ferguson Act, see Zachman v. Erwin, 186 F. Supp. 691, 694 (S.D. Tex. 1960); United States v. Meade, 179 F. Supp. 868, 874-75 (S.D. Ind. 1960). 
fraction of the benefits will be payable in fixed amounts,"28 the variable annuity is not insurance since it guarantees nothing. Although $\mathrm{Mr}$. Justice Brennan joined in the opinion of the Court, he elaborated on the reasoning of the majority in a concurring opinion. He noted that the type of regulation by state authorities relied upon by Congress in making the insurance exemptions from the securities legislation and in passing the McCarran-Ferguson Act did not relate to disclosure but rather looked to the maintenance of solvency, and he pointed out that such regulation was as inappropriate to the type of investment represented by the variable annuity as was the disclosure required by securities regulation to the normal insurance policy. He found such state regulation unrelated to the policies sought to be implemented by the Securities Act and the Investment Company Act. ${ }^{29}$

Concluding that a definition of insurance should be adopted which was consistent with statutory aims, Mr. Justice Brennan observed:

There is no reason to suppose that Congress intended to make an exemption of forms of investment to which its regulatory scheme was very relevant in favor of a form of state regulation which would not be relevant at all. ${ }^{30}$

Thus he added to the majority test of whether there are any fixed benefits the test of whether state regulation is adequate to warrant the withholding of the investor protection afforded by federal securities legislation. Both of these considerations are certainly pertinent since the exemptions undoubtedly envisioned a contract with more attributes of insurance than mere terminology and an unspecified mortality risk. It should be noted, however, that neither opinion can be read as stating that meeting its test is sufficient to bring the exemptions into play, but only that it is necessary. ${ }^{31}$

Conceding that a variable annuity was a security subject to registration under the Securities Act, the Prudential Insurance Company applied to the SEC in 1963 for a ruling that, as the issuer of a

28359 U.S. at 71.

29 Although the Securities Act makes no declaration of policy, $\S 1$ (b) (1) of the Investment Company Act probably speaks for both:

[I]t is hereby declared that the national public interest and the interest of investors are adversely affected-

(1) when investors purchase, pay for, exchange, receive dividends upon, vote, refrain from voting, sel1, or surrender securities issued by investment companies without adequate, accurate, and explicit information, fairly presented, concerning the character of such securities and the circumstances, policies, and financial responsibility of such companies and their management.

54 Stat. 790 (1940), 15 U.S.C. $\$ 80 a-1$ (b) (1) (1964).

30359 U.S. at 80.

31 Since the Court held the variable annuity was not insurance, any language describing what is sufficient to be insurance would have been dictum. 
variable annuity, it need not conform to the Investment Company Act. Prudential reasoned that, since VAIIC's sole business was the issuance of securities, the Supreme Court had held only that VALIC was not a company whose "primary and predominant business activity is the writing of insurance," 32 and that this holding did not apply to Prudential, only a small part of whose business would be the issuance of variable annuities. ${ }^{33}$ The SEC declined to issue the ruling, pointing out that, although Prudential was the issuer of the variable annuity for purposes of the Securities Act, under the Investment Company Act the issuer was the "Investment Fund" (Separate Account), which was a separate entity from the insurance company and not entitled to the company's exemption. Thus the SEC found it necessary to regulate only the activities of the Investment Fund, ${ }^{34}$ claiming thereby to leave outside its domain any regulation of the insurance activities of Prudential. ${ }^{35}$ The Third Circuit affirmed ${ }^{36}$ on two grounds: (1) to qualify as a company within the definition of "investment company"37 the Investment Fund need not be "an identifiable business entity with some sort of internal organi-

32 The complete definition of "insurance company" is included in note 13 supra.

33 Prudential Ins. Co. of America, SEC Investment Company Act Release No. 3620 (1963), aff'd, 326 F.2d 383 (3d Cir.), cert. denied, 377 U.S. 953 (1964).

34 In this connection the SEC stated:

This commission has not the qualification, much less any desire, to become involved in matters of insurance regulation. . . .

The mortality guarantee and other insurance promises, and the management of and interest in the assets behind them, are the business of the insurance company, and its stockholders and policy holders as such.

Prudential Ins. Co. of America, SEC Investment Company Act Release No. 3620, at 7-8 (1963).

35 Query how well this dichotomy will work in practice. In Variable Annuity Life Ins. Co. of America, SEC Investment Company Act Release No. 4686 (1966), VALIC requested exemptions from $\$ \$ 18(\mathrm{~d})$ and $22(\mathrm{~g})$ of the Investment Company Act (restricting the issuance by mutual funds of warrants and securities in exchange for services, respectively) so that it might issue options for its stock to its employees as a form of compensation under a plan provided for by $\S 422$ of the Internal Revenue Code of 1954. Since VALIC is not "externalized," see note 9 sipra, but rather operates the Separate Account as a subdivision within the VALIC corporate structure, the company itself is registered as an investment company and its common stock comes within $\$ \S 18(\mathrm{~d})$ and $22(\mathrm{~g})$. The requests were denied on two grounds. Granting options in VALIC's stock would adversely affect the holders of interests in the Separate Account, since management would have an incentive to take undue risks with the fund in order to maximize the advisory fee (which is calculated on the net asset value of the fund). Secondly, the options would dilute VALIC's equity and make difficult any future financing made necessary if increased costs due to unfavorable mortality experience should reduce reserves, because the uncertainty as to whether the options would be exercised would make accurate evaluation of an equity interest in VALIC impossible, and this would discourage investment. Thus the SEC is in the position of regulating VALIC for the purpose of assuring continued payments on the mortality guarantee-purely an insurance obligation, which is clearly inconsistent with the SEC's position in the Prudential case. See note 34 supra.

36 Prudential Ins. Co. of America v. SEC, 326 F.2d 383 (3d Cir.), cert. denied, 377 U.S. 953 (1964).

37 "Investment company" is defined in note 1 supra, 
zation"38 since both the House and Senate committee reports, as well as the act itself, evinced an intent to adopt the SEC's report as the basis for the Investment Company Act, and this report treated as investment companies nonlegal entities wholly dependent on their organizers for their continued existence; and (2) the act did not intend a general exemption of entities dependent on exempted organizations, since it specifically exempted both banks and bank common trust funds. ${ }^{39}$

The treatment of the term "issuer" as having different meanings for the two acts is amply justified by the different schemes of regulation which the two acts employ. The Securities Act seeks to hold responsible for the information published in accordance with its requirements all persons associated with the issuance of the security. ${ }^{40}$ Hence an expansive interpretation of the term "issuer" is appropriate. The Investment Company Act imposes an active system of regulation, having specific requirements as to such specialized matters as contracts with investment advisors, redemption obligations and association with investment bankers. ${ }^{41}$ This detailed regulation should be imposed on, and is relevant to, only the entity actively performing the function of an investment company. Thus a more restrictive interpretation of "issuer" is appropriate for the Investment Company Act. $^{42}$

With the prospect of regulation under both the Securities Act and the Investment Company Act, the insurance industry naturally was eager to create a variable annuity which would qualify as insurance, allowing the contract to be sold free of such restrictions on competitive activities as those relating to advertising and maximum commissions which these acts now impose on mutual funds. Almost immediately after the $V A L I C$ decision was handed down, it was suggested in the literature that any variable annuity some of whose benefits were guaranteed would qualify for the statutory exemptions. ${ }^{43}$ In response to

38326 F.2d at 387. Section 2(a) (8) of the Investment Company Act defines "company" as

a corporation, a partnership, an association, a joint-stock company, a trust, a fund, or any organized group of persons whether incorporated or not; or any receiver, trustee in bankruptcy or similar official or any liquidating agent for any of the foregoing, in his capacity as such.

54 Stat. 791 (1940), 15 U.S.C. \$ 80a-2(a) (8) (1964).

39 Investment Company Act $\$ 3(\mathrm{c})(3), 54$ Stat. 798 (1940), 15 U.S.C. §80a-3 (c) (3) (1964).

40 Sections 11 and 12 of the Securities Act make an extremely broad group of persons civilly liable for false statements in a registration statement or prospectus. 48 Stat. 82 (1933), as amended, 15 U.S.C. $\$ \$ 77 \mathrm{k}-1$ (1964).

41 Investment Company Act $\$ 10$ (b) (3), 54 Stat. 806 (1940), 15 U.S.C. $\$ 80 a-10$ (b) (3) (1964); \$15(a), 54 Stat. 812 (1940), 15 U.S.C. $\$ 80 a-15$ (a) (1964); $\$ 22$ (e), 54 Stat. 824 (1940), 15 U.S.C. $\$ 80 a-22$ (e) (1964).

42 The acts are singularly unhelpful in defining "issuer," both using language to the effect that an issuer is one "who issues or proposes to issue any security." Securities Act of 1933, \$2(4), 48 Stat. 74 (1933), 15 U.S.C. $\$ 77 b(4)$ (1964); Investment Company Act $\$ 2(a)(21), 54$ Stat. 793 (1940), 15 U.S.C. $\$ 80 a-2(a)$ (21) (1964). The term "issue" is nowhere defined in either act.

43 See Comment, 61 Mich. L. Rev. 1374 (1963); Comment, 1959 WasH. U.L.Q. 206. 
the objection in the majority opinion that the issuers of variable annuities "guarantee nothing to the annuitant except an interest in a portfolio of common stocks or other equities-an interest that has a ceiling but no floor," 44 United Benefit offered such a floor with its Flexible Fund Annuity (FFA). ${ }^{45}$

The FFA makes two guarantees to the annuitant: (1) if he dies during the pay-in period, the entire amount of premiums including commissions are refunded to a beneficiary regardless of the investment performance of the "Separate Account"; (2) on a sliding scale rising to $100 \%$ after ten years, the annuitant is guaranteed that he cannot lose his net premiums after commissions, ${ }^{46}$ regardless of the investment performance of the Separate Account. ${ }^{47}$ Accumulated earnings receive no guarantee regardless of the length of time since they were reinvested. $^{48}$ United Benefit attempted to remove the FFA further from the securities field by providing that, if the annuitant did not avail himself of the opportunity to redeem his entire investment in cash at the end of the pay-in period, the pay-out would be in fixed amounts according to the standard annuity table in effect at the time the contract was issued or at the time of the first annuity payment by the company, whichever would be more favorable to the annuitant.

A suit by the SEC to enjoin United Benefit from issuing the FFA without complying with the Securities Act and the Investment Com-

44 SEC v. Variable Annuity Life Ins. Co. of America, 359 U.S. 65, 72 (1959) $(V A L I C)$. Query as to what this language means. Any way that the annuitant's investment might decrease in value is mirrored by a way that it might appreciate as well. Thus the ceiling would also seem to be non-existent.

45 Its full name is Annual Premium Flexible Fund Retirement Annuity.

46 The commission rates are $50 \%$ the first year, $9 \mathrm{t} / 2 \%$ the next nine years and $5 \%$ for all subsequent years. Brief for Appellant, p. 4, SEC v. United Benefit Life Ins. Co., 359 F.2d 619 (D.C. Cir. 1966). Unless the pay-in period extends for longer than twenty-one years, the commissions on the FFA exceed the statutory maximum of $9 \%$ required by $\$ 27$ (a) of the Investment Company Act. 54 Stat. 829 (1940), 15 U.S.C. $\$ 80 \mathrm{a}-27$ (a) (1964).

47 Taking into account commissions, the percentage of premiums which are guaranteed is as follows:

$\begin{array}{cc}\begin{array}{c}\text { years since } \\ \text { beginning } \\ \text { of pay-in }\end{array} & \begin{array}{c}\text { percentage of total } \\ \text { net premiums subject } \\ \text { to givarantec }\end{array} \\ 1 & 25.0 \\ 2 & 38.6 \\ 3 & 46.2 \\ 4 & 52.2 \\ 5 & 57.7 \\ 10 & 86.5 \\ 15 & 89.3 \\ 20 & 90.7\end{array}$

Since the average commission rate never actually comes down to $5 \%$, the percentage guarantee of total premiums can never rise to $95 \%$, although the guarantee of premiums net of commissions is $100 \%$ after ten years. Brief for Petitioner, p. 5, SEC v. United Benefit Life Ins. Co., - U.S. - (1967).

48 Assuming quarterly payments, if the fund is able to achieve an average annual return equal to $4 \%$ compounded quarterly, at the end of twenty years one-third of the annuitant's interest in the fund will not be subject to the guarantee. See GusHEE, Financial Compound Interest and Annuity Tables 416 (3d ed. 1961). 
pany Act was dismissed by the District Court for the District of Columbia ; ${ }^{49}$ the Court of Appeals for the District of Columbia Circuit recently affirmed, ${ }^{50}$ and certiorari has been granted by the Supreme Court. ${ }^{51}$ The affirmance by the court of appeals was grounded on two considerations: (1) the contract cannot be divided into pay-in and payout periods as the SEC desired to do in order to assume jurisdiction only over the former; and (2) United Benefit had assumed a substantial part of the investment risk in making the guarantee. ${ }^{52}$

Severability of the policy into two periods was denied on the ground that the $V A L I C$ opinions and common sense "indicate that a challenged policy should be viewed as a whole in order to test its amenability to federal regulation." ${ }^{\text {"53 }}$ Although the majority opinion in $V A L I C$ did not advert to this issue at all, perhaps the court of appeals in United Benefit was referring to the following language in the concurring opinion:

\section{Much bewilderment could be engendered by this case if} the issue were whether the contracts in question were "really" insurance or "really" securities—one or the other. It is rather meaningless to view the problem as one of pigeonholing these contracts in one category or the other. ${ }^{54}$

This language does not lead to the conclusion that the FFA must be viewed as a single entity throughout its existence, but rather that it is

49 SEC v. United Benefit Life Ins. Co., Civil No. 3096-62, D.D.C., Apr. 5, 1965. 50 SEC v. United Benefit Life Ins. Co., 359 F.2d 619 (D.C. Cir. 1966).

51385 U.S. 918 (1966).

52 The substantial risk test was found by Chief Judge Bazelon to be implicit in both the majority and concurring opinions in the $V A L I C$ case. $359 \mathrm{~F} .2 \mathrm{~d}$ at 622 . This would seem to follow from the fact that a token guarantee, i.e., a guarantee which is less than substantial, would represent mere form, and it would not make federal regulation irrelevant in the sense outlined by Mr. Justice Brennan. Further support for the requirement of a substantial guarantee is found in SEC v. Ralston Purina Co., 346 U.S. 119 (1953), where the Court held that the applicability of provisions for exemption in the Securities Act "should turn on whether the particular class of persons need the protection of the Act." Id. at 125. Since state insurance regulation does not relate to the investment policies pursued by the management of the Separate Account, annuitants need the protection of the Securities Act unless the guarantee is substantial enough to protect them from adverse performance of the Separate Account.

The court of appeals also indicated that in holding for United Benefit it was motivated by a desire to avoid "freezing" insurance into the form existing at the time of the passage of the securities legislation. However, arguments addressed to the problem of freezing insurance do not seem to be helpful. Although all the opinions in $V A L I C$ admonish against it, 359 U.S. at 71, 76, 101, they seem to be saying no more than that Congress did not intend to restrict the insurance exemption to those policies in existence at the time of enactment. This leaves unanswered the question which the United Benefit case presents-is a minimum guarantee of $100 \%$ of net premiums on a variable annuity sufficient to qualify it for the insurance exemptions? Reference must still be made to the intent of Congress in exempting various forms of insurance; inquiry into the securities aspects of the contracts is still relevant; and drawing the line between insurance and securities is still just as difficult.

53359 F.2d at 623.

54359 U.S. at 80. See also Mearns, The Commission, the Variable Annuity, and the Inconsiderate Sovereign, 45 VA. L. REv. 831 (1959). 
misleading to concentrate on either the insurance or security aspect of the contract to the total exclusion of the other at any point in time. Since the FFA is partially insurance during the pay-in period (if the financial insurance provided by the guarantee is the sort of insurance which Congress had in mind in writing the insurance exemptions into the securities legislation $)^{55}$ and wholly insurance during the pay-out period, the language quoted above would not prohibit the consideration of all the aspects of the contract during the pay-in period itself to determine whether or not it is a security during that period alone.

The court of appeals' denial of severability is difficult to support conceptually inasmuch as the FFA specifically allows it and the advertising stresses it. If the annuitant desires to withdraw his investment at maturity (or at any time prior thereto), he is free to do so; newspaper advertisements point out in block letters the availability of "Lifetime Retirement Income or Lump Sum Cash!" 56 Thus the contract permits the use of the FFA as an investment vehicle of the mutual fund type with no significant difference except the level of the fees, which is higher than that permitted under the Investment Company Act for commissions in the sale of periodic payment plans, ${ }^{57}$ or that charged by the mutual fund industry for managing a portfolio. ${ }^{58}$

Nor does the combination of the investment vehicle represented by the FFA during the pay-in period with a single payment fixed annuity render the two devices inseparable for regulatory purposes. Presumably if an open-end investment company (mutual fund) bought an investment guarantee insurance policy for all its shareholders equivalent to the guarantee on premiums offered by United Benefit, ${ }^{59}$ and also arranged with an insurance company to provide an annuity contract to any shareholder at the end of the periodic plan pay-in period, the SEC would not be deprived of its jurisdiction over the investment company,

55 The possibility of bankruptcy of the insurance company makes this guarantee no more safe than any other fixed obligation of the company. The court of appeals in United Beitefit seems to have ignored this problem:

Were the annuitant to invest on his own in the stock market, or even in so-called "safe" securities like bonds and mortgages, he would not have this guarantee, and his principal would never be absolutely secure.

359 F.2d at 623 .

56 Joint Appendix, vol. 2, p. 26, SEC v. United Benefit Life Ins. Co., 359 F.2d 619 (D.C. Cir. 1966).

57 See note 46 supra. A periodic payment plan is an agreement whereby the purchaser makes regular acquisitions in fixed dollar amounts. Although there is no contractual obligation to continue the purchases, the large initial commission (frontend load) makes the failure to complete the plan very costly to the investor. The SEC has recommended the abolition of the front-end load. MUTUaL Fund REPORT 247.

68 United Benefit charges the fund approximately $1 \%$ of the net asset value in return for managing the fund and providing the guarantees. The usual charge by the mutual fund industry for investment advisory services alone is $.5 \%$ per year. Id. at 89 ; H.R. REP. No. 2274, 87th Cong., 2d Sess. 28 (1962) (the Wharton Report).

59 The cost of such a policy should not be very high-United Benefit calculates that an annual charge of $.5 \%$ of the net asset value is sufficient to cover the mortality risk during the pay-in period and the minimum cash value guarantee. Brief for Appellant, p. 30, SEC v. United Benefit Life Ins. Co., 359 F.2d 619 (D.C. Cir. 1966). 
although it would not have the power to regulate the insurance company. The SEC is currently engaged in the regulation of a mutual fund (Advisers Fund, Inc.) which offers in conjunction with its periodic payment plan the promise of an insurance company that the purchaser may buy a single-payment fixed annuity at the rates in force during the pay-in period. ${ }^{60}$ Since this offer has been regulated for years, it is difficult to question the feasibility of regulation of the FFA on the restricted basis which the SEC asserts is necessary.

The other ground for the decision of the court of appeals was that United Benefit had assumed a substantial part of the investment risk by guaranteeing the return of net premiums. The court noted:

Presumably no insurance company will undertake a guarantee in any policy if there is a substantial possibility that it will have to resort to surplus to satisfy that obligation. Instead of denoting the company's risk, we think the concept refers to the annuitant's risk of losing money . . . over the course of the investment period. By guaranteeing principal ... United has assumed a substantial part of this risk during the deferred period of the contract. ${ }^{61}$

This language can be read only as stating that United Benefit underwrites a substantial part of a nonsubstantial risk. Although the annuitant's risk of losing money is substantially taken over by United Benefit, this risk is the same as the likelihood of making a payment on the guarantee. Any such payment must come from surplus, and the first sentence in the quoted language above admits that the probability that the company will ever have to make such a payment is very small. That the risk underwritten by United Benefit is not very great is further borne out by the experience of the mutual fund industry. Assuming that every fund for which statistics are available had purchased a guarantee equivalent to that provided by the FFA for its shareholders, and the shareholder retained his interest at least until the guarantee was at a maximum (at the end of ten years), no payment thereon would have been necessary if the interest were fully redeemed at the end of the ten-year periods $1956-1965$ or 1953-1962.62 (The latter period maximizes the adverse effect of the 1962 market break since the guarantee is at its highest at the end of the period.) Studies made by United Benefit indicated that in only one case involving the worst drop in stock prices over the twenty-seven year period from 1933 through 1960 would a payment have been required on the guarantee, and it would have amounted to only $.6 \%$ of net premiums paid in. ${ }^{63}$ (1967).

60 Brief for Petitioner, p. 33, SEC v. United Benefit Life Ins. Co., - U.S. -

61359 F.2d at $622-23$.

62 Weisenberger, Mutual Fund Charts and Statistics (1963 \& 1966 eds.). (1967).

63 Brief for Petitioner, p. 6, SEC v. United Benefit Life Ins. Co., - U.S. - 
The problem raised by the sufficiency of the guarantee points up the difficulty with a rigidly quantified standard used as the sole test for exemption: if the only qualification for obtaining the exemption is to meet some court-created minimum level guarantee (which smacks of administrative regulation rather than judicial process), the door is opened to a variety of minimal compliances which evade the intent of the regulation. Even assuming that the setting of a specific standard which the guarantee must meet would be both sufficient and effective as the sole test, there remain difficulties in choosing the correct percentage. A very low guarantee (such as a $.5 \%$ annual return) offers little protection to the investor over that afforded by the FFA. As the required guarantee rises, the necessity of meeting the guarantee will force the insurance company to invest heavily in fixed-income securities, thus losing the very feature which the variable annuity is intended to provide-variation in asset value to reflect changes in the price level. Should the minimum be set high enough, the industry is told, in effect, that the only variable annuity which it can offer free of federal regulation is the participating annuity, since the latter has traditionally been exempt from federal securities regulation. ${ }^{64}$

Since the Court in $V A L I C$ was concerned only with what was not insurance, it never reached the question of what would suffice to qualify for the exemptions. The majority and concurring opinions certainly nowhere state that any specific minimum guarantee would be sufficient in itself to render the exemptions applicable. Mr. Justice Brennan's opinion adverts to another test which would be relevant but which was not considered in United Benefit-the manner in which the policy is offered to the public. ${ }^{65}$ Such a test finds supports in the language of the Securities Act: so long as the terms of advertising suggest that what is being sold is a security, the FFA is "an interest or instrument commonly known as a security."66 The test was first applied in SEC v. C. M. Joiner Leasing Corp. ${ }^{67}$ in which the Supreme Court held oil leases to be securities by virtue of sales literature which emphasized the investor's opportunity to participate in the financial success which would follow the underwriter's drilling a producing well:

64 Mr. Justice Brennan was not unaware of the problem of what would be a sufficient guarantee but advanced no suggestion for solving it, possibly on the ground that a policy with a sufficient guarantee would be too expensive to be saleable. See 359 U.S. at 90.

65 A mutual insurance company selling a participating annuity "is not committed by its literature to perform part of the job of a common-stock investment trust." 359 U.S. at 90 .

66 For the complete definition of "security," see note 1 sipra.

The exemption for insurance policies in $\$ 3(a)(8)$ of the Securities Act may have been predicated on the sales approach. See H.R. REP. No. 85, 73d Cong., 1st Sess. 15 (1933): "The insurance policy and like contracts are not regarded in the commercial world as securities offered to the public for investment purposes." (Emphasis added.) Although not offered as such, to the extent that an insurance policy accumulates cash value, it represents a form of investment.

67320 U.S. 344 (1943). 
Novel, uncommon, or irregular devices, whatever they appear to be, are also reached if it be proved as matter of fact that they were widely offered or dealt in under terms or courses of dealing which established their character in commerce as "investment contracts," or as "any interest or instrument commonly known as a 'security." The proof here seems clear that these defendants' offers brought their instruments within these terms.

The test ... is what character the instrument is given in commerce by the terms of the offer, the plan of distribution, and the economic inducements held out to the prospect. In the enforcement of an act such as this it is not inappropriate that promoters' offerings be judged as being what they were represented to be. ${ }^{68}$

Hence, in order to qualify for the exemptions, a variable annuity must be offered in terms which do not stress its suitability as a vehicle offering an opportunity for financial return. However, this test is not independent of the $V A L I C$ criterion regarding the adequacy of a guarantee and the consequent adequacy of state regulation. The greater the protection provided by the guarantee, the less concerned the court need be with the method of sale since state regulation will provide more investor protection as the guarantee rises. Neither test ever becomes totally irrelevant-neither a policy offered as a security with a high guarantee nor a policy offered as insurance with a nominal guarantee would qualify for the exemption.

It is not clear what the result would be if these two tests were applied to the FFA. The brief for the SEC in the court of appeals points out that newspaper advertisements included a banner proclaiming "NEW OPPORTUNITY FOR FINANCIAL GROWTH," but it also states that "the sales emphasis . . . is upon the necessity of providing security for old age and upon the claim that this can be done by expert management and diversification of risk ..." To The issue appears to be one of fact for the trial court to determine on remand.

The economic inducement test would seem to answer another of the court's problems in United Benefit: how to distinguish between the variable annuity and the participating annuity, through which the annuitant participates in the favorable investment or mortality experience of the insurance company itself. ${ }^{71}$ Policies such as the latter are not

68 Id. at 351-53.

60 Brief for Appellant, p. 10, SEC v. United Benefit Life Ins. Co., 359 F.2d 619

(D.C. Cir. 1966).

${ }^{70} \mathrm{Id}$. at 30 . (Emphasis added.)

71359 F.2d at 623 n.10. 
offered under circumstances stressing the suitability of the purchase for growth of capital; the participation aspect appears to be merely an added "come-on" rather than the main selling point of the investment. It was on this basis that Mr. Justice Brennan distinguished the two types of policies, ${ }^{72}$ although the participating annuity is further distinguishable in that the participation is small and does not fluctuate, while the guarantee is high.

If the FFA is determined to be a security, besides registering under the Securities Act and the Investment Company Act, United Benefit or the Separate Account will have to register as a broker or a dealer under the Securities Exchange Act of 1934. ${ }^{73}$ If the Separate Account utilizes its own sales force to merchandise the FFA, it appears to satisfy the definition of "dealer" since it buys securities (for investment purposes) and sells them at a mark-up ${ }^{75}$ in the form of participation certificates. If either United Benefit or independent general agents sell the FFA, they will have to register as brokers, since they are "engaged in the business of effecting transactions in securities for the account of others, ${ }^{, 76}$ namely the annuitant and the Separate Account. ${ }^{77}$ The latter appears to be the practice followed with VALIC's independent general agents. ${ }^{78}$

The principal effect of such registration will be to require the salesmen to qualify as securities salesmen by passing a test administered by the SEC or the National Association of Securities Dealers, depending

72359 U.S. at 90. Mr. Justice Brennan also distinguished the participating annuity on the ground that its holder participates in the favorable mortality experience of the company, which is never the case with the variable annuity.

73 Section 15(a) (1) of the Securities Exchange Act provides:

No broker or dealer (other than one whose business is exclusively intrastate) shall make use of the mails or of any means or instrumentality of interstate commerce to effect any transaction in, or to induce the purchase or sale of, any security ... otherwise than on a national securities exchange, unless such broker or dealer is registered in accordance with subsection (b) of this section.

48 Stat. 895 (1934), as amended, 15 U.S.C. $\$ 78 o(a)(1)$ (1964).

74 Section 3(a) (5) of the Securities Exchange Act defines a "dealer" as any person engaged in the business of buying and selling securities for his own account, through a broker or otherwise, but does not include a bank, or any person insofar as he buys or sells securities for his own account, either individually or in some fiduciary capacity, but not as a part of a regular business.

48 Stat. 883 (1934), 15 U.S.C. \$78c(a) (5) (1964).

75 Assuming that the definitional requirement of "a regular business" in $\S 3$ (a) (5) implies that the dealer must anticipate a profit from his endeavors, the mark-up is a necessary element to the definition of "dealer." Thus funds selling through brokerdealers as well as funds charging no sales commissions (no-load funds) are not "dealers" since neither anticipates a profit from the sale of securities.

${ }^{76}$ Securities Exchange Act $\S 3(\mathrm{a})(5), 48$ Stat. 895 (1934), as amended, 15 U.S.C. $\$ 78 o(a)(1)(1964)$.

77 For a general discussion of the broker-dealer definition, see 2 Loss, SECurITIES Regulation 1295-1301 (1961).

78 See Conference on Securitres Regulation 54-57 (Mundheim ed. 1965). 
on with whom the broker-dealer decides to register. ${ }^{79}$ This test need not be that administered to securities salesmen generally since the act expressly provides for classification according to the nature of the securities sold. ${ }^{80}$

Some insurance companies have argued that compliance with federal securities legislation is prohibited by state regulation, but in view of the receptivity of state legislatures to proposals for modifications to permit the issuance of variable annuities ${ }^{8 \mathrm{I}}$ and the exemptive powers of the SEC under section 6(c) of the Investment Company Act, ${ }^{82}$ this objection would seem to be unfounded.

If the FFA is found to use a sales approach which makes it competitive with mutual funds, the application of the securities legislation is desirable on at least two grounds. First, selling practices can then be regulated to insure that the investor understands fully the nature of the investment he is purchasing and is not pressured by extravagant claims as to the results to be expected from expert financial management. Under the Securities Exchange Act the SEC will have the power to insure that salesmen will fully understand the merchandise they handle, as well as to exclude undesirables from selling variable annuities. Perhaps a more important consideration from a policy standpoint is that

79 Section 15(b) (8) of the Securities Exchange Act provides in part:

No broker or dealer registered under section 15 of this title shall, during any period when it is not a member of a securities association registered with the Commission under section $15 \mathrm{~A}$ of this title, effect any transaction in, or induce the purchase or sale of, any security (otherwise than on a national securities exchange) unless such broker or dealer and all natural persons associated with such broker or dealer meet such specified and appropriate standards with respect to training, experience, and such other qualifications as the Commission finds necessary or desirable.

78 Stat. 570 (1964), 15 U.S.C. $\$ 780$ (b) (8) (1964). Section 15A(b) (5) requires in similar language that no one may join a national securities association unless he measures up to similar standards established by the association with the approval of the SEC. 78 Stat. 574 (1964), 15 U.S.C. $\$ 780$ A (b) (5) (1964). The act leaves open to the broker-dealer the choice of whether to register with the SEC or the National Association of Secturities Dealers.

Because of the substantial similarity of the regulatory pattern implemented by the Securities Exchange Act and the Investment Company Act with respect to corporations subject thereto, the application of the former will probably have no additional effect other than to compel registration of United Benefit or the Separate Account as a broker or dealer and proper training of the salesmen.

80 Section 15(b) (8) of the Securities Exchange Act further provides:

The Commission shall establish such standards by rules and regulations, which may-

(A) appropriately classify brokers and dealers and persons associated with brokers and dealers (taking into account relevant matters, including types of business done and nature of securities sold).

(B) specify that all or any portion of such standards shall be applicable to any such class.

(C) require persons in any such class to pass examination prescribed in accordance with such rules and regulations.

Identical provisions appear as a part of $\$ 15 \mathrm{~A}(\mathrm{~b})(5)$ regulating broker-dealers registered with a national securities association.

81 See, e.g., N.J. Stat. AnN. 17:35A (1963).

82 See, e.g., Variable Annuity Life Ins. Co. of America, 39 S.E.C. 680, 685-91 (1960); Equity Annuity Life Ins. Co., 39 S.E.C. 674 (1960). 
the SEC will not be subject to the pressures of competitive regulation. If the FFA is permitted to compete directly with mutual funds without the handicaps inherent in federal securities regulation, ${ }^{83}$ the mutual fund industry will argue that its regulation should be relaxed so that it may compete more effectively with the mammoth sales campaigns which the insurance industry can mount free of federal regulatory fetters. Competitive regulation would be undesirable for a number of reasons-investors would not receive the full protection which securities legislation currently affords them; the quality of regulation would slip to the lowest common denominator so that everyone might "compete effectively"; and public confidence in the regulatory process would be eroded. ${ }^{84}$

83 One advantage accruing to a non-registered variable annuity is that its sponsor is not required to disclose the tax penalty which may result from not being registered as an investment company. Section 852 of the Internal Revenue Code grants a pass-through to registered investment companies so that no income tax is levied at the corporate level if they comply with certain requirements which they normally satisfy. However, if the FFA should not be registered under the Investment Company Act, a tax may be assessed at the corporate level on the amount by which the net realized long-term capital gain exceeds the net realized short-term capital loss. See INT. REv. CoDE of 1954, \$ 804(a) (2). Inasmuch as it is long-term capital gains which the Separate Account is intended to accumulate, this represents a substantial disadvantage to the participant. No tax will be assessed at the participant level until the pay-out period begins in the case of a non-registered variable annuity. This is not the case with a registered variable annuity, since the Separate Account must distribute annually at least $90 \%$ of its taxable income to its participants in order to qualify for pass-through treatment. INT. REv. CODE of 1954, §852(a) (1). However this tax deferral is partially offset by the fact that capital gains retain their preferred status in the hands of participants owning registered variable annuities, whereas all earnings, regardless of character, are taxed at ordinary rates when paid to the beneficiary of the non-registered variety. See INT. REv. CODE OF 1954, §852(b) (3) (B) ; Treas. Reg. \$1.72-11 (b) (2) (1956).

s4 See Mundheim, How the United Benefit Case May Affect the SEC's Chances in Congress, Institutional Investor, March 1967, p. 22. 